
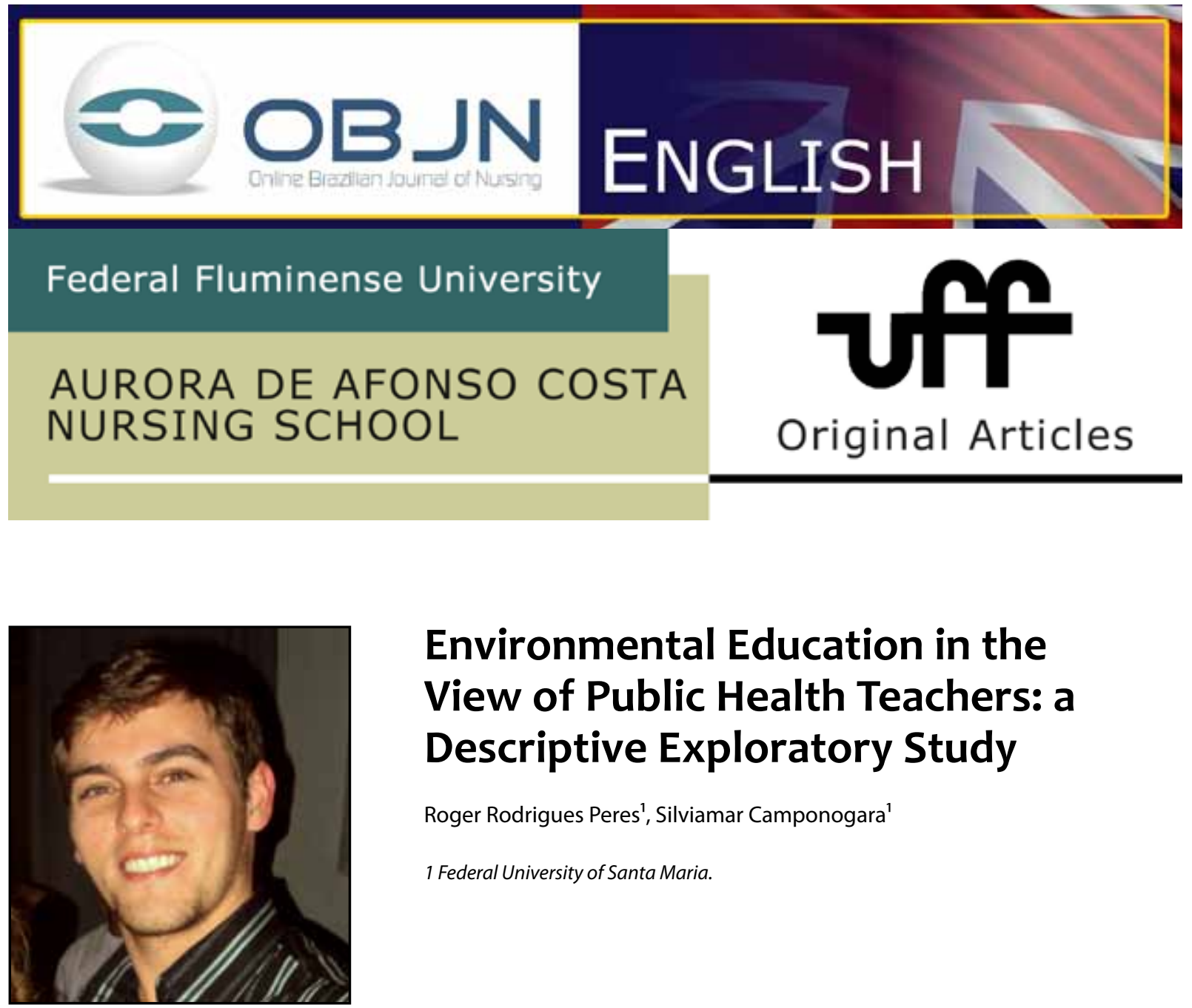

\title{
Environmental Education in the View of Public Health Teachers: a Descriptive Exploratory Study
}

\author{
Roger Rodrigues Peres' ${ }^{1}$, Silviamar Camponogara' \\ 1 Federal University of Santa Maria.
}

\begin{abstract}
Aim: to analyze the vision of professors of public health on environmental education. Method: This is a qualitative study, of the descriptive-exploratory type, conducted with eight teachers of collective health at an institution of higher education in southern Brazil who were intentionally selected. Data were collected from August to October 2011, through semi-structured interviews, and investigated based on the proposed framework for content analysis. Results: Subjects believed that environmental education involves awareness and behavioral changes, and these should also add criticality to social environmental, biological and cultural issues, and others as important as the action of environmental preservation. Discussion: It appears that the approach to the subject was incipient. For this reason, there is need for formal inclusion of the subject in the curriculum of undergraduate courses. Conclusion: It is concluded to be necessary to foster a debate among teachers and educational institutions, with a view to include environmental education in vocational training in health.
\end{abstract}

Descriptors: Health; Environment; Public Health; Faculty. 


\section{INTRODUCTION}

There is an environmental crisis that have become obvious and disturbing starting from the 1960s, mainly characterized by the ecological irrationality of the dominant patterns of production and consumption and the limits of global economic growth ${ }^{(1)}$. The landmark that sparked this fact was the First United Nations Conference on the Human Environment held in Stockholm in 1972, which increased the discussion on the impacts of environmental destruction on human life.

In the wake of this debate, ideas on new concepts began to emerge in order to seek to solve issues relating to accelerated environmental destruction and its negative influence on different aspects of human life. Among these proposals, we can highlight those relating to sustainable development and environmental education (EE). The first was motivated by the desire to stop environmental destruction without compromising the process of economic advancement of the society; and the second, with the purpose of establishing actions aimed at environmental preservation, especially focused on the search for awareness of the subject.

Since the First International Meeting on Environmental Education, held in 1975 in the city of Belgrade (Yugoslavia), the struggle for environmental conservation has gained strength. Thereafter, education began to be understood as a social practice that can produce movements of transformation and change of the alarming levels of life quality of and environmental degradation ${ }^{(2)}$.

In Brazil, this argument gained a formal nature after the enactment of Law No. 9,795, of April 27, 1999, which establishes the basic principles of EE, demarcating what constitutes an essential process so that individuals and community can build social values, knowledge, skills, attitudes and competencies for the conservation of the environment. Furthermore, it should be developed as an integrated, continuous and permanent educational practice in all levels and modalities of formal education $^{(3)}$.

However, despite the legal provisions, it is notorious that this type of education is not a target for debate in some teaching scenarios. What has happened is that the issue has been more prominent in the levels of primary and secondary schooling. With respect to higher education, there seem to be major gaps on the topic. This reality is even more evident in the scenario of professional training in health: despite recent curriculum changes, this still has its focus on technical and non-preventive practices. Environmental issues do not occupy an important position in studies that are related to health promotion strategies in the relationship between man and the environment ${ }^{(4)}$.

We should also mention that, usually, the approach to the health and environment interface, when performed by means of $E E$, is included in the content of public health, probably due to the proximity of these workers and the community, living with their proble$\mathrm{ms}$, whether social, economic or environmen$\mathrm{tal}^{\left({ }^{(5)}\right.}$. Also we credit to this link the fact that the situations of housing, food, access to health services, occurrence of vector-borne diseases and exposure to air pollutants are factors that increase the vulnerability of the exposed populations' episodes of climate change, causing aggravation of clinical findings and an awakening of public health to the effects of the environment on human health ${ }^{(6)}$.

From this perspective, we observe the absolute need for an education focused on environmental issues in all their complexity 
and in different areas of knowledge, also incorporating it as inherent in the development of health actions, which must be revised following professional training ${ }^{(7)}$. Thus, the role of the University in the social and environmental trajectory becomes unquestionable because it accumulates functions of research, teaching and extension, being responsible for the formation of professional citizens who will act in various sectors of society. Thus, this institution becomes a forum for dialogue with the school and society, enabling the expression of new values, knowledge and new social and environmental realities ${ }^{(8)}$.

Based on these, it is considered important to understand what the teachers connected to the conference on environmental health education think, given its essential role among future professionals, in order to instigate reflective thinking regarding health, social and environmental problems.

Therefore a study guided by the following question was developed: what is the vision of teachers in the area of health related to collective health on environmental education in professional training? To this end, we decided, as the aim of the research, to analyze the vision of teachers of health related to collective health on environmental education in professional training.

\section{METHOD}

The study was guided by a qualitative approach, which enables the acquisition of information regarding the subjectivity of the subjects, capturing the meanings about the phenomena under study ${ }^{(9)}$. The research is characterized as exploratory and descriptive and was conducted with eight teachers connected with public health.
Participants were related to various departments of the health area of a public institution of higher education in southern Brazil: Nursing, Physical Therapy, Speech Therapy, Dentistry and Community Health. These were selected by lot from a list of teachers who worked with public health, linked to the departments mentioned above. The closure of the sample obeyed the criterion of data saturation. The inclusion criteria were: being a teacher in the health area, working in the institution and having been working for more than a year in the post.

Data were collected during the months from August to November 2011 through semi-structured interviews, consisting of ten questions on this topic. Such questions incited exposure of perceptions about the environment, environmental issues, and the relationship between health, environment and environmental education. Interviews were conducted by the researchers (including signing the Informed Consent Form) in a reserved place, recorded and later transcribed by them. The subjects were identified by the letter "I", meaning "interview", and the number of the respective interview.

Researchers evaluated based on the proposed framework for content analysis, according to the following steps: meeting of the data corpus (interviews carried out and transcribed by the authors); initial reading of the findings (or pre-analysis, seeking significant expressions in the speeches of the participants in the study); in-depth reading (with the aim of establishing categories of analysis); and interpretative analysis of the categories, followed by discussion with the pertinent literature ${ }^{(10)}$.

The study followed the precepts indicated for the research with humans, according to Resolution $196 / 96$ of the National Health 
Council and the data collection occurred only after institutional approval and approval of the institution's Research Ethics Committee (CAAE No. 0160.0. 243000-11).

\section{RESULTS}

The main categories derived from the survey are presented below, interspersed with statements by the subjects and the interpretation of findings.

Environmental education: behavior, consciousness and health promotion

The teachers were encouraged to reflect on their perception of the environment, health and teaching practice, so that subsequently they could formulate and present their vision in terms of EE. They pointed out that EE is not something simple and timely; rather, they associate it with the experience of the subject, to the point of reflecting changes in attitudes and behaviors that permeate the daily lives of individuals. Thus, the extracts of testimonials below demonstrate the complexity with which the subject is treated.

[...] I hope that environmental education is taken in their daily lives; experienced, and that it should focus on behavior change. I think it has to be a change in attitude, thinking about the way we relate to the environment. So education means reviewing habits, routines, work processes, from the family to the university; whether it is in everyday life, in a discipline or in a planned, organized or informal practice [...] (I02)
[...] We cannot think that environmental education means not only not polluting the air or not littering on the street. It's much more, and if I have the consciousness of not littering on the street this will also reflected in other attitudes that are related to the environment. So it is education; an expanded look at the things that are in our context [...] (103)

Manifestations refer to $E E$ as a revision of attitudes, change in behavior and the way people relate to the environment, denoting a care targeted at environmental preservation actions and its complex approach, which is nonetheless consistent with the ideas expressed in the literature. Some interviewees indicate that education goes beyond specific actions; that is, "it is much more", "an extremely wide thing", intertwining with healthcare knowledge.

Extrapolating the merely conservationist actions, which are constantly reinforced by the media, is a challenge today, since humans should feel touched, sensitized and open to dialogue and understanding of the current crisis. Therefore, it is understandable that the education understood by the subjects has its origin precisely in this need for "something more", and also in the concern in terms of the issues that are intrinsic to the environment, whether social, economic, natural, educational, or cultural, among others.

Thus, it is the duty of the individual to feel moved by the theme to live and work the subject at the same time. The internalization of actions aimed at environmental preservation practices is a critical condition for their everyday concreteness; but it should not be the final point of the EE as viewed in the conception of the teachers. 
The idea that EE is embraced by the lack of awareness on the part of society was also addressed by teachers. However, we can highlight the fact that this awareness should be encouraged in others according to these manifestations, with no need of the deponents being the target of this awareness; or else, by the inclusion of vocational training in the process. In this sense, the statements indicate a certain trivialization of EE, which may have its basis in widely disseminated jargon.

\section{[...] Environmental education is this awareness that we need to develop in people that everything, all waste is reprehensible [...] (103)}

Another finding is related to the link the teachers expressed between environmental education and health promotion in vocational training, highlighting that the conception of the subjects on health can bring implications for their perception on environmental issues.

[...] Whoever is alert in terms of the technical issue of healthcare, anyone who is concerned about taking action, I think we forget it sometimes [...] Then I realize that, for anyone who is involved with the technique, it seems to be linked to the training; now if you already have health promotion running in your veins, I already think it has to be different [...] (I01)

Well I do not know why, our area is the area of public health, so we have this direct connection with the environmental part [...] (I07)

The reports show the close link of $E E$, with regard to actions in terms of health pro- motion, to the field of public health. Such an approach also allows us to infer that teachers identify themselves as environmental educators, realizing the proximity and interdependence of knowledge.

The perception of the proximity of EE in terms of health promotion shows an expanded health and environmental awareness, so that, by unifying them, we corroborate to a greater wellness, concerned not only with private or community health today, but also with global and intergenerational instances.

It is understood that, although there is some comprehension in terms of the complexity of the concept of EE among the study subjects, there has been no further debate on the subject yet. The idea that environmental education should be part of everyday life is interconnected to an apparent trivialized conception of necessary "environmental awareness". However, the expressions that indicate the interface between environmental education and public health can be understood as foreshadowing a reflective process on the issue, pointing to the possibility of new meanings about the relationship between health and the environment in teaching practice.

This may denote a very positive impact on the process of training in health, in order to seek valuation of the environmental dimension as inherent to the health care process.

However, the lack of a systematic approach to the subject and the official inclusion of this subject in the curricula of health courses can be considered major obstacles to achieving the purpose of further discussion on the health and environment interface in the professional training process. Moreover, we can add the fact that the training of teachers may not have been contemplated with reflections on this subject, due to a historical moment in which the realization in terms of 
EE, which covers aspects related to health and environment interface, has not yet been addressed in all its complexity.

The fragility of environmental education in vocational training in health: reflecting on responsibilities

The EE approach has been identified as an important guideline to be followed by teachers and heads of educational institutions at various levels of education, including higher education. However, this still does not seem to be a widely found reality. In the investigated institution, this question became evident from the reports of the interviewees, when asked about their vision in terms of the discussion of EE in professional health education:

[...] But I do not see the health areas or nuclei supporting the idea or showing concern. I think people are still a bit alienated. If you have your personal values related to the environment in your daily routine or in your practice and you still comment, do and practice, but if you do not have it as a value, I think you may forget it [...] (I01)

There is no one. I do not see anyone talking about environmental education in the health area, or in the training [...] It is very individualized still, but it is not established in any way. (102)

The EE approach to professional education in health is still very nascent or nonexistent. This finding raised by the subjects deserves attention, considering the future role of professionals in training with regard to environmental aspects that influence the health of the population and by which professionals hold responsibility directly or indirectly.

Given the fragility of EE in training, we can emphasize the need for dialogue between faculty trainers towards a reflection on these issues, and also a discussion on how to provide the inclusion of this perspective in the political-pedagogical projects of the courses. We might also reiterate the imperative of harmony and complementarity in the contents worked and also encourage the necessary interdisciplinary approach that the subject requires.

Thus, incorporating EE in the different health courses becomes essential so that the current undergraduates are aware of or become familiar with the subject, especially knowing that these will become responsible for instigating such reflection, either in the community, in the hospital environment or even in the training of new professionals. This perception leads us to reflect on another point of the research, which consists in the vision of teachers of their responsibility in the EE approach in vocational training.

Two points that have contributed to the achievement of new realities in health education emerged from the reports, highlighting the sense of commitment to change and the example that should be inherent to the teaching profession. In this strand, the subjects believe they have meaningful engagement with the subject, a finding evident in the extracts below.

[...] The responsibility is immense and I think this process needs to evolve. We need to create ways and means so that we can internalize and incorporate it [...] (102) 
Every teacher has the responsibility in every way. He has a responsibility to be a model for the student who is graduating. He has responsibility as a public servant, working in a public university, and also on environmental issues, if we talk about training [...] (108)

The sense of responsibility is present, at least at discourse level. Although some teachers say they have been using this type of approach, we can also observe in the statements the understanding that a movement of awareness is still needed that instigates reflection in terms of environmental issues and their relation to health. Thus, perhaps, the issue could be tackled with greater security.

Articulating knowledge constructed by study groups working with EE with the specificities of each area of teaching, engendering reflections on the history of such contents as the current reality, and forms of intervention, among others, may be ways of approaching teaching reality, deconstructing fears and encouraging a sense of responsibility.

There is a crucial need to address the issue with the teachers, so that they instigate this reflection on graduation from their own realities and experiences. It is also understood that the strategy of being an example in the development of actions for sustainable nature is essential to approach any education with an environmental interface.

I think all the responsibility of the teacher is a matter of giving an example [...] I believe that we are educators in all dimensions, not only in our professional area. Example is one of the best educational tools [...] (I01)
[...] Then my responsibility towards the student is immense, and in order to have repercussions, I need to practice what I say. So I guess that, in relation to education at any level, all of us have a responsibility, especially us, since we have a different training [...] (104)

Being an example is, in reality, a way of encouraging reflection in terms of environmental issues in students; however, the actions or environmentally responsible behavior should be minimally featured or quoted, whether in the classroom, in the practice of primary care, in hospital practices, or in day-to-day teaching. We reaffirm this aspect because, at times, subjects report being imbued with environmentally responsible practices, but say at the same time that they had never highlighted or reflected on the environmental theme.

Being attentive to the need for highlighting the environmental perspective in their attitudes and ways of dealing with health in teaching may be another aspect that demonstrates and brings optimism to strengthen a perception of increased health. Thus, there will be training for professionals responsible for and imbued with the importance of the health and environment interface, generating a proactive area of the health movement toward ethical assumptions that underpin environmental education as part of the training process of creating health.

\section{DISCUSSION}

The statements of the teachers, who refer to EE as a review of attitudes and of the relationship established with the environment, 
corroborate the literature on the understanding that it is not enough just to change individuals and prompt behaviors regarding the contemporary environmental problems in order to achieve an ideal social and environmental well-being. This perspective is evidenced in a study that points to environmentally responsible actions, especially in the area of hospital health, as being mechanized, that is, not originated in the reflection on environmental care. Due to this conclusion, the research confirms that such actions may be related to the little available knowledge on the subject and, with the feature of labor activity, marked by hospital standardization and routinization ${ }^{(11)}$.

Thus it is understood that, through EE, which offers strategies for reflection on current environmental issues, current students and/or future professionals may derive greater benefits from the reflection upon their own behavior, motivating themselves for the construction of actions and a responsibility for thinking in terms of the environment ${ }^{(11)}$.

It is noteworthy that in this article, we not disregard the responsibilities of professionals working in both the hospital setting and in primary health care. They also need to discuss environmental issues with their managers through a process of continuous education, systematic and comprehensive, based on a reflective process that problematizes the concepts, beliefs and values of those involved in order to develop environmentally conscious practices ${ }^{(12)}$.

With this perspective, we reinforce the need to address environmental issues with the necessary complexity in the different scenarios, demanding an immediate new attitude, an actual renewal of values, of citizenship, commitment to social, care, respect, responsibility and interest, that is, an ethic in terms of taking care of the environment ${ }^{(13)}$.
The emphasis laid by professors on EE with regard to the awareness of people is simplistic because, although such education represents a challenge when it comes to changing behavior in relation to the environment, it is understood that it is too complex to point to "awareness" as a complete resolution of problems without, first, considering an awareness, reflection or thematic approach to the subject's life in an instigating way.

This perception of understanding and change is also evident in studies with students in the health field. Although students are attentive to contemporary environmental problems, they do not perform actions that refer to environmental care, delegating this commitment to others at times ${ }^{(14)}$.

In a move contrary to this simplification of environmental and health issues, teachers emphasize, through awareness, the complexity of rapprochement between EE and collective health. We attribute this to the fact that the field of public health is one that seeks to view the objects of its action in its context, considering its particularities. Such a perspective occurs in opposition to the paradigm, often identified in hospitals, in which the multidisciplinary team develops its activities with a view to the fragmentation of the human being ${ }^{(15)}$.

Thus, we reaffirm the need for the training of health professionals to explore the potential of Public Health, in order to awaken in students the acquisition of knowledge that relates health to the environment, in order to go beyond the acquisition of content about the biological, divided and finished body ${ }^{(15)}$.

Environmentally sustainable educational practices indicate pedagogical proposals centered on criticality and the emancipation of individuals, focusing on changing behavior and attitudes, the development of social orga- 
nizations and collective participation ${ }^{(16)}$. While teachers understand themselves as agents of community participants - and more than that, as diffusers or instigators of knowledge - the manifestation "example is one of the best educational tools" becomes coherent, given that their attitudes also instigate reflection of those around them.

We should also point out that, in this proposal for reflective and engaged education, focusing on knowledge and practices built with, but not for teachers and students, EE differs substantially from environmental information, which needs attention in teaching practices. Environmental information is no more than a relationship focused on elaborating and transmitting decontextualized and "depoliticized" content, thus not introducing effective changes into reality through the construction of a critical or intentionally engaged knowledge $\mathrm{e}^{(16)}$.

Given these projections for the inclusion and organization of the EA in training, we defend the idea that the approach happens transversally, that is, not as part of a specific matter, but as one which pervades by all disciplines ${ }^{(17)}$. Although we understand such an approach as ideal, we can also understand that there are obstacles to it, such as the difficulty of transforming institutionalized dominant paradigms, which, in addition to fragmenting the knowledge and educational content, also makes them legitimate and rooted in knowledge and global economic interests ${ }^{(1)}$.

Therefore, working on the conceptualization of environmental problems, the processes that constitute it, and its registration within a social rationality and a certain development process, becomes an alternative for change, especially when you know that the incorporation of environmental knowledge with scientific practices and teachers goes beyond a requirement for updating of the university curricula from the internalization of an environmental "dimension" and an ecological thinking ${ }^{(1)}$.

\section{CONCLUSION}

From this study it can be inferred that teachers visualize environmental education as a complex process that involves the inmost being, the subjectivity and the rationality of human beings, reflecting in their actions, behaviors and attitudes toward the environment, but which is also set up in the need for raising awareness of the issue. The subjects demonstrate proximity between the actions of health promotion in the field of public health and environmental education, awakening a sense of responsibility and, at the same time, concern about the incipience and weakness of the approach of EE in health professional education. This perspective brought us to another finding of the study, in which being an example for the student is the main form of encouraging reflection in terms of environmental issues.

The perception in terms of environmental education, constructed by teachers, needs to be understood beyond a change in behavior. For this it is necessary to add criticality to the social, environmental, biological and cultural problems, among others, which are considered as important as the proper actions of environmental preservation.

The need to seek alternatives to encourage teachers and students to reflect on environmental issues becomes evident, rescuing the feeling of co-responsibility shown by the study subjects, as well as ways on how this issue can be inserted in the political and pedagogical projects of the different courses. 
We may add that, in order to understand the regionality of the survey, we consider important to develop new studies to further investigate the issue and provide subsidies for intervention in reality, since Environmental Education in vocational training in health increasingly becomes imperative when opposed to the current socio-environmental crisis scenario.

\section{REFERENCES}

1. Leff E. Saber ambiental: Sustentabilidade, racionalidade, complexidade e poder. 8. ed. Petrópolis: Vozes; 2011.

2. Carvalho LM, Tomazello MGC, Oliveira HT. Pesquisa em educação ambiental: panorama da produção brasileira e alguns de seus dilemas. Cad. Cedes. [internet] 2009 [cited 2013 Abr 20]; 29(77):13-27. Available from: http://www. scielo.br/pdf/ccedes/v29n77/a02v2977.pdf

3. Lei n. ${ }^{\circ}$ 9795, de 27 de abril de 1999 (BR). Dispõe sobre a educação ambiental, institui a política nacional de educação ambiental e dá outras providências. Diário Oficial da República federativa do Brasil. Brasília: Poder Legislativo.

4. Schmidt RAC. A questão ambiental na promoção da saúde: uma oportunidade de ação multiprofissional sobre doenças emergentes. Physis [internet] 2007 [cited 2013 Abr 20; 17(2):373-392. Available from: http://www. scielo.br/pdf/physis/v17n2/v17n2a10.pdf

5. Beserra EP, Alves MDS, Pinheiro PNC, Vieira NFC. Educação ambiental e enfermagem: uma integração necessária. Rev Bras Enferm [internet] 2010 [cited 2014 Abr 20]; 63(5):848852. Available from: http://www.scielo.br/pdf/ reben/v63n5/26.pdf

6. Ministério da Saúde (Brasil), Organização Pan-Americana da Saúde. Mudanças climáticas e ambientais e seus efeitos na saúde: cenários e incertezas para o Brasil. Brasília: Organização Pan-Americana da Saúde; 2008.
7. Camponogara S, Cardoso ALK, Ramos FRS. Uma revisão sistemática sobre a produção científica com ênfase na relação entre saúde e meio ambiente. Ciênc. saúde coletiva. [internet] 2008 [cited 2013 Abr 20]; 13(2):427-439. Available from: http://www.scielo.br/pdf/csc/ v13n2/a18v13n2.pdf

8. Graciolli SRP, Júnior AJV, Costa MV, Zanon ÂM. A educação ambiental num programa de pós-graduação em ecologia e conservação e a visão docente. Rev. eletrônica Mestr. Educ. Ambient.[internet] 2010 [cited 2013 Abr 20]; 25:35-48. Available from: http://www.seer.furg. $\mathrm{br} / \mathrm{remea} / \mathrm{article} / \mathrm{view} / 3369 / 2018$

9. Gil AC. Métodos e técnicas de pesquisa social. São Paulo: Atlas; 2011.

10. Bardin L. Análise de Conteúdo. Lisboa: Edições 70; 2007.

11. Camponogara S, Ramos FRS, Kirchhof ALC. Reflexivity, knowledge and ecological awareness: premises for responsible action in the hospital work environment. Rev. Latino-Am. Enfermagem. [internet] 2009 [cited $2013 \mathrm{Abr}$ 04]; 17(6):1030-1036. Available from: http:// www.scielo.br/pdf/rlae/v17n6/16.pdf

12. Camponogara $S$, Soares $S A$, Terra MG, Santos TM, Trevisan CM. Nurses involved in management of hospital residues: a descriptive study. Online Braz J Nurs. [internet] 2012 [cited 29 Abr 2013]; 11(2): 289-304. Available from: http:// www.objnursing.uff.br/index.php/nursing/ article/view/3621/pdf_1

13. Freitas $L$, Joventino $E$, Ximenes $L$, Vieira $N$, Moreira R. The ethics of nursing care for environmental crises. Online Braz J Nurs. [internet] 2012 [cited 2013 Abr 29]; 11(3):893-06. Available from: http://www.objnursing.uff.br/index. php/nursing/article/view/3833/pdf_1

14. Camponogara S, Erthal G, Viero CM, Diaz PS, Soares SGA, Peres RR. The perception of students of the area of health about the environmental problems: a descriptive study. Online Braz J Nurs. [internet] 2012 [cited 2012 Abr 20]; 11(2): 376-91. Available from: http:// www.objnursing.uff.br/index.php/nursing/ article/view/3767 
15. Sena J, Cezar-vaz MR. A relação saúde/ambiente nos processos de formação do profissional enfermeiro: um ensaio teórico. Rev. eletrônica Mestr. em Educ. Ambient. 2010; 24:265-273.

16. Jacobi PR, Tristão $M$, Franco MIGC. A função social da educação ambiental nas práticas colaborativas: participação e engajamento. Cad. Cedes, Campinas.[internet] 2009 [cited 2013 Abr 20]; 29(77):63-79. Available from: http://www.scielo.br/pdf/ccedes/v29n77/ a05v2977.pdf

17. Camponogara S, Diaz PS, Rossato GC, Peres RR, Soares SA, Erthal GE, Viero CMV. Interface between health and environment in professional education in health. Acta Paul Enferm. [internet] 2012 [cited 2013 Abr 20]; 25(6):9027. Available from: http://www.scielo.br/pdf/ ape/v25n6/v25n6a12.pdf
All authors participated in the phases of this publication in one or more of the following steps, in accordance with the recommendations of the International Committee of Medical Journal Editors (ICMJE, 2013): (a) substantial involvement in the planning or preparation of the manuscript or the collection, analysis or interpretation of data; (b) preparing the work or performing critical review of the intellectual content; (c) approval of the version submitted. All authors declare, for appropriate action, that the content related to all aspects of the manuscript submitted to OBJN is their responsibility. They ensure that issues related to the accuracy or completeness of any part of the article have been properly investigated and resolved, exempting, therefore the OBJN of any joint participation in any imbroglios on the matter at hand. All authors declare that they have no conflict of interest, whether financial or of relationship, to influence the drafting and/or interpretation of the findings. This statement was digitally signed by all authors as recommended by the ICMJE, whose model is available in the following website: http://www.objnursing.uff.br/normas/DUDE_ final_13-06-2013.pdf

Received: 04/29/2013

Revised: 07/14/2014

Approved: 07/14/2014 